\title{
Correlation between Serum Ferritin and Cardiac Troponin I in Major Beta Thalassemia Children
}

\author{
Muhammad Ali Shodikin ${ }^{1 *}$, Renny Suwarniaty ${ }^{2,3}$, Susanto Nugroho ${ }^{2,3}$ \\ ${ }^{1}$ Faculty of Medicine, Jember University, Jember, Indonesia \\ ${ }^{2}$ Departement of Child Health, Faculty of Medicine, Brawijaya University, Malang, Indonesia \\ ${ }^{3}$ dr. Syaiful Anwar Public Hospital, Malang, Indonesia
}

\begin{abstract}
Major beta thalassemia (MBT) is a hereditary disease which synthesies defects in beta chains of haemoglobin, it is causes red blood cell destruction and the symptoms of anemia. Red blood cell destruction, frequent blood transfusion and low adherence to routine use of iron chelator lead to iron accumulation in the heart, liver and endocrine organs. Accumulation of iron in the myocard can lead acute myocardial infarction. One of cardiac markers that had been used for the diagnosis of myocardial infarction was cardiac troponin I (cTnI). The aim of this research is find the correlation between serum ferritin levels and cTnI in MBT children. A descriptive analytic research was conducted using a cross sectional design. The subjects were divided into 2 groups, the MBT group and the control group. In both groups, the serum ferritin and cTnI levels ere evaluated. Data were analyzed using t-test and Pearson correlation test. Eleven children in the MBT group and 11 children in the control group were involved in this study. In the MBT group, the mean of serum ferritin and cTnI levels were $4292.5 \mu \mathrm{g} / \mathrm{L}$ and $0.20 \mathrm{ng} / \mathrm{mL} \mathrm{respec-}$ tively. The mean of serum ferritin levels in the MBT group were higher than in the control and statistically significant $(p=0.0004)$. The mean of serum ferritin levels in the MBT group were higher than in the control and statistically significant $(\mathrm{p}=0.0004)$. The mean of serum $\mathrm{cTnI}$ in the MBT group were higher than in the control, but statistically not significant $(\mathrm{p}=0.82)$. In the MBT group, there was a weak corellation between serum ferritin and cTnI levels $(r=0.34)$.
\end{abstract}

Keywords: children, cTnI, ferritin, Major beta thalassemia

\section{INTRODUCTION}

Major beta thalassemia (MBT) is a hereditary disease which synthesies defects in beta chains of haemoglobin. MBT causes red blood cell destruction, leads to anemic symptoms and need for regular blood transfusions [1, 2, 3]. Haemolysis and regular blood transfusions can lead to iron overload in the liver, endocrine organs and myocardium [1,3] Iron overload can be evaluated easily and verified by measuring serum ferritin levels $[1,4,5]$. High serum ferritin levels increase the risk of myocardial infarction in adults.6,7 Myocardial infark can be diagnosed by the cardial biomarker cardiac troponin I (cTnI) [8]. In Indonesia, the correlation between serum ferritin level and cTnI in MBT children has never been studied.

\footnotetext{
*Corresponding author:

Muhammad Ali Shodikin

Faculty of Medicine, Jember University

Jalan Kalimantan, Jember 68121, Indonesia

E-mail: alipspd@yahoo.com
}

\section{MATERIALS AND METHODS \\ Study design}

A descriptive analytic research was conducted using a cross sectional design, on May 2015, at the Pediatric Departement and Clinical Pathology Departement of Syaiful Anwar General Hospital (SAGH) Malang, Indonesia, and approved by the ethics committee of SAGH. The subjects were divided into 2 groups, the MBT group and the control group.

\section{The patients}

Inclusion criteria of MBT subjects were children 1 -18 years old, diagnosed as MBT by haemoglobin electrophoresis, needing regular blood transfusion and approved by their parents after informed consent. Inclusion criteria for the control groups were children 1 -18 years old, not diagnosed as MBT, never had regular blood transfusion and approved by their parents after informed consent. Respondents were excluded if they had autoimmune haemolytics anemia, iron deficiency 
anemia, aplastic anemia, severe infections, malignancy, severe malnutrition and congenital or acquired heart disease.

\section{Assays}

In both groups were perform laboratory examination of peripheral blood to checks the serum ferritin and cTnI levels. Serum ferritin levels were measured by immunoturbidimetry assays using FERR3:ACN165, Roche/Hitachi cobas c system analyzer (US). Serum cTnI level were measured by sandwich immunochroma-tography using AIM TROPONIN I Q Rapid test (Indonesia).

\section{Statistical analyses}

The differences in serum ferritin and cTnI levels between the MBT and control groups were analyzed by a t-test. The correlation between serum ferritin and cTnI levels in the MBT group were analyzed by a Pearson correlation test. Confidence interval 95\% $(\alpha=0.05)$ Data were analyzed using SPSS for Windows 16.0.

\section{RESULTS AND DISCUSSION}

The subjects of this study were 22 children, 11 children in the MBT group and 11 children in the control group. The mean of age of the MBT and the control groups were 123 months and 69 months respectively. In the MBT group, 8 of 11 were male and 7 of 11 were in good nutritional status. In the control group, 7 of 11 were male and 7 of 11 were had a good nutritional status. In the MBT group, palor was in all patients, Cooley's face in 9 of 11, spleen enlargement in 10 of 11 and short stature in 9 of 11 . Whereas in the control group, there was no palor, Cooley's face, spleen enlargement or short stature. All subjects in the MBT group were got Packed Red Cell (PRC) transfusions regularly every $1-2$ months as well as iron chelator medication and no one of control group got PRC transfusions or iron chelator (Table 1).

Complete blood count result showed the average of haemoglobin level before transfusion in the MBT group was $6.5 \mathrm{~g} / \mathrm{dL}$ that lower than in the control group whose haemoglobin level was $12.5 \mathrm{~g} / \mathrm{dL}$. The average of erythrocytes in the MBT group and control groups were $2.9 \times 10^{6} / \mu \mathrm{L}$ and $4.86 \times 10^{6} / \mu \mathrm{L}$ respectively. The average of leukocyte in the MBT group and control groups were $9.02 \times 10^{3} / \mu \mathrm{L}$ and $7.6 \times 10^{3} / \mu \mathrm{L}$ respectively. The average of thrombocyte in the MBT group and control groups were $247.8 \times 10^{3} / \mu \mathrm{L}$ and $294.9 \times 10^{3} / \mu \mathrm{L}$ respectively (Table 1 ) .
Table 1. Subjects characteristics

\begin{tabular}{|c|c|c|}
\hline Characteristics & $M B T$ & Control \\
\hline Respondents (n) & 11 & 11 \\
\hline Average age (months) & 123 & 69 \\
\hline Gender (Male / Female) & $8 / 3$ & $7 / 4$ \\
\hline \multicolumn{3}{|l|}{ Nutritional status } \\
\hline - Well nourished & $7 / 11$ & $7 / 11$ \\
\hline - Under nourished & $4 / 11$ & $3 / 11$ \\
\hline - Obese & 0 & $1 / 11$ \\
\hline \multicolumn{3}{|l|}{ Clinical signs } \\
\hline - Pale & $11 / 11$ & $0 / 11$ \\
\hline - Cooley’s face & $9 / 11$ & $0 / 11$ \\
\hline - Short stature & $9 / 11$ & $0 / 11$ \\
\hline - Splenomegali & $10 / 11$ & $0 / 11$ \\
\hline Regular PRC transfusion & $11 / 11$ & $0 / 11$ \\
\hline Iron chelator medication & $\begin{array}{l}11 / 11 \\
(\text { mean } \pm S D)\end{array}$ & $\begin{array}{l}0 / 11 \\
(\text { mean } \pm S D)\end{array}$ \\
\hline Haemoglobin (g/dL) & $6.5 \pm 1.04$ & $12.5 \pm 1.03$ \\
\hline Erythrocites $\left(10^{6} / \mu \mathrm{L}\right)$ & $2.9 \pm 0.5$ & $4.86 \pm 0.4$ \\
\hline Leukocytes $\left(10^{3} / \mu \mathrm{L}\right)$ & $9.02 \pm 7.2$ & $7.6 \pm 4.01$ \\
\hline Thrombocytes $\left(10^{3} / \mu \mathrm{L}\right)$ & $247.8 \pm 221.9$ & $294.9 \pm 84.99$ \\
\hline
\end{tabular}

The mean of serum ferritin level in the MBTgroups was $4292.5 \mu \mathrm{g} / \mathrm{L}$ higher than it was in the control groups with only $136.2 \mu \mathrm{g} / \mathrm{L}$. Statistics analyses by $\mathrm{t}$ test showed there was a significant difference in serum feritin levels between the MBT and control groups ( $p$ value $=0.0004)$. The mean of $c T n I$ in the MBT group was $0.22 \mathrm{ng} / \mathrm{mL}$, higher than it was in the control group with only $0.20 \mathrm{ng} / \mathrm{mL}$. Statistics analyses by $\mathrm{t}$ test indicated difference of cTnI level between the MBT and control groups was not significant ( $\mathrm{p}$ value $=0.82$ ) (Table 2). In the MBT group, the result of Pearson correlation test showed there was a weak correlation between serum ferritin and cTnI levels $(\mathrm{r}$ value $=0.34$ ) (Figure 1).

The age average of the children in the MBT group was 10 years 3 months. MBT is usually diagnosed when the children are under 2 years old [9]. In this re-

Table 2. Serum ferritin and cTnI levels

\begin{tabular}{cccl}
\hline Parameter & $\begin{array}{c}M B T \\
(\text { mean } \pm S D)\end{array}$ & $\begin{array}{c}\text { Control } \\
(\text { mean } \pm S D)\end{array}$ & P value \\
\hline Ferritin $(\mu \mathrm{g} / \mathrm{L})$ & $4292.5 \pm 2660$ & $136.2 \pm 168.8$ & 0.0004 \\
$\mathrm{cTnI}(\mathrm{ng} / \mathrm{mL})$ & $0.22 \pm 0.24$ & $0.20 \pm 0.23$ & 0.82 \\
\hline
\end{tabular}




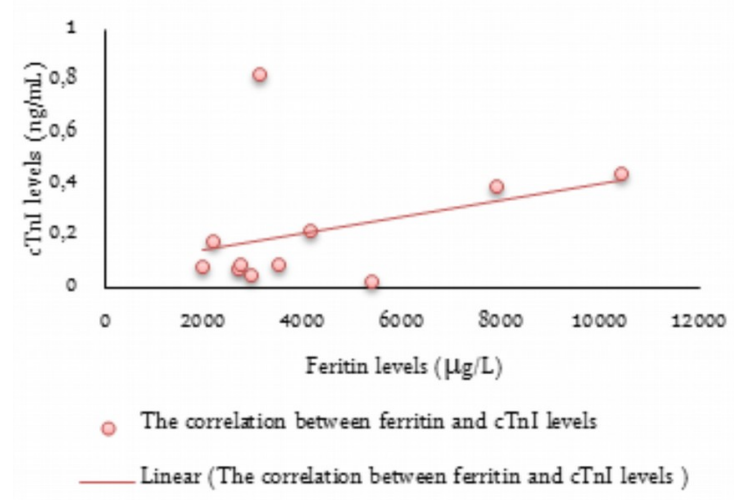

Figure 1. Correlation between serum ferritin and cTnI level in MBT children

search, respondents in the MBT group had got regular PRC transfusion every 1-2 months for many years. The older MBT patiens are more susceptible to complications, such as heart, liver and endocrines disturbance [10].

Eight out of 11 children in the MBT group were male, the male to female ratio being 8:3. Another study in thalassemic children in Surabaya had a male to female ratio of $44: 17$ [11] but in Jakarta this ratio was $37: 36$ [12]. Male and female proportions in MBT patients are influenced by autosomal ressessive inheritance and not sex chromosomal linked [2, 9].

Seven children out of 11 in the MBT group had good nutritional status. It was shown they had had proper medical and nutritional care. All the patients (11/11) in the MBT group were pale, caused by erythrocytes damage and ineffective erythrocytes synthesis due to globin chain defect $[13,14]$. Furthermore, almost all patients in the MBT group had splenomegalli but there were no one in the control group. The spleen was the main organ for erythrocyte degradation [2].

A majority of children $(9 / 11)$ in the MBT group had short stature, whereas, all children in the control group had normal stature. In MBT patients, the short stature was caused by growth hormon disturbance, chronic hypoxia due to chronic anemia and cardiovascular disturbance [10]. A majority of the children (9/ 11) in the MBT group suffered from Cooley's face caused by erythropoitic expansion in the bone marrow leading to the skull and face bone deformities [13].

Complete blood count results showed the average of haemoglobin levels before transfusion in the MBT group were lower than those in the control group. Haemoglobin levels in thalassemic children were less than $7 \mathrm{~g} / \mathrm{dL}$ when diagnosed at the first time [9]. Anemia in the MBT children was caused by erythrocyte damage and ineffective erythrocyte synthesis due to globin chain defect $[13,14]$. The laboratory tests for establishing the diagnoses of MBT were erythrocyte index, peripheral blood smear and haemoglobin electrophoresis [15]. The average leukocyte and thrombocyte counts in both groups were within the normal limits.

The average serum ferritin level in the MBT group was $4292.5 \mu \mathrm{g} / \mathrm{L}$, which was not only higer than that in the control group but also higher than normal limits $(20-200 \mu \mathrm{g} / \mathrm{L})$. Statistics analyses by $\mathrm{t}$ test showed significant differences in serum ferritin levels between the MBT and control groups ( $p$ value $=0.0004)$. A study in China also found high serum ferritin levels in MBT patients, $2754 \mu \mathrm{g} / \mathrm{L}$ [16]. Another study on Egyptian children with MBT also found high serum ferritin levels, $4510 \mu \mathrm{g} / \mathrm{L}$ [17]. Serum ferritin levels of more than $1000 \mu \mathrm{g} / \mathrm{L}$. was indicate iron overload [18].

Iron overload in MBT patients is caused by erythrocyte damage, frequent PRC transfusions and increased iron absorbtion [19]. Continual iron overload will lead to iron deposition in the liver, heart and endocrine organs [1, 3]. Non transferin-bound forms of iron (NTBI) in the cytoplasmic can induce the convertion of $\mathrm{Fe}^{2+}$ to $\mathrm{Fe}^{3+}$ and lead increase free radicals such as reactive oxygen species [20]. Free radicals will induce lipid peroxidation in the cell organels such as lysosom, mitochondria and cytoplasmic membranes. Lipid peroxidation can disturb the cell function and cause cell necrosis including miocytes in the myocardial layer [20]. Iron chelator medication will not only reduced the iron deposition and labile iron but also reduced free radicals [4].

The average cTnI levels in the MBT group was 0.22 $\mathrm{ng} / \mathrm{mL}$ which was higher than those in the control group at $0.20 \mathrm{ng} / \mathrm{mL}$, but the differences in cTnI levels between both groups were not statistically significant $(\mathrm{p}=0.82)$. Based on equipment standard were used in this study, the serum cTnI levels were normal if less than $0.8 \mathrm{ng} / \mathrm{mL}$. This result showed the serum cTnI levels in both groups were within normal limits. The normal serum cTnI levels indicated there was no myocardial injury in either groups. The myocardial injury leads to myocyte damage and induces the leakage of cTnI into the systemic circulation. Increasing cTnI levels can be detected although in the intial myocardial injuries even if echocardiography can not detect it [19].

The correlation between the serum ferritin and cTnI levels in the MBT group was weak positive correlation ( $\mathrm{r}$ value $=0.34$ ). It was mean increasing of serum feritin level will increase the serum cTnI level. Serum 
cTnI level higher than normal had $100 \%$ sensitivity and $96.3 \%$ specificity for diagnosing the myocardial infarction [21]. cTnI serum levels was higher than normal indicate mycordial injury [22]. Higher than normal cTnI levels increase the mortality rates [21].

Antioxydant enzymes such as catalase, superoxide dismutase and glutation give cell protection from oxidative stress $[23,24]$. The effects of free radicals and oxidative stress on MBT patient can be neutralized by antioxidant additives such as Vitamin $\mathrm{E}$ and $\mathrm{N}$-asetylcystein [25].

The results of this study showed that serum cTnI levels in the MBT group was within normal limits although serum ferritin level was high. This might been cused by regular iron chelator medication; the good nutritional status of the majority of MBT children and the consumption of sufficient antioxidant such as Vitamin A, Vitamin C and Vitamin E.

\section{CONCLUSIONS}

The average serum ferritin levels in the MBT group were higher than those in the control group and the statistical difference was significant. The average serum cTnI levels in the MBT group were higher than in the control group, but this was not statistically significant. There was a weak positive correlation between serum ferritin and cTnI levels in the MBT group.

\section{ACKNOWLEDGMENT}

\section{REFERENCES}

1. Gallanello R, Origa R (2010) Beta-thalassemia. Orphanet Journal of Rare Disease 5:11.

2. Nienhuis AW, Nathan DG (2012) Pathophysiology and clinical manifestations of the $\beta$-thalassemias. Cold Spring Harb Perspect Med. 2:a011726.

3. Talluri SB, Datta V, Guttula SGB ( 2013) An overview on thalassemia. International Research Journal for Inventions in Pharmaceutical Science 1:1-12.

4. Flemming RE, Ponka P (2012) Iron overload in human disease. N Engl J Med. 366:348-59.

5. Faruqi A, Ahmad SI, Ahmed ST (2014) Early detection of cardiac iron overload in thalassemia major patients. Journal of Rawalpindi Medical College 2014;18:166-9.

6. Silvia WD, Biswas S, Uthappa S, Shetty (2003) Ferritin, a potent threat for acute myocardial infarction? JAPI 51:947-59.

7. Bharati BK, Chandrakar S (2013) Serum ferritin - A potential threat and risk factor for acute myocardial infarction. International Journal of Pharmacy and
Biological Science 07:13.

8. Chiu A, Chan WK, Cheng SH, Leung CK, Choi $\mathrm{CH}$ (1999) Troponin I, myoglobulin, and mass concentration of creatine kinase-MB in acute myocardial infarction. QJ med 92:711-8.

9. Jha R, Jha S (2014) Beta thalassemia-a review. Journal of pathology of Nepal 4: 663-671.

10. Grow K, Abrol P, Vashist M, Yadav R, Sharma S (2013) Associated complication in beta thalassemia patients. IOSR Journal of Pharmacy 3: 22-25.

11. Suwarniaty R, Ontoseno T, Permono B, Sastroasmoro S (2007) Pengaruh kadar feritin serum terhadap fungsi ventrikel kiri pada thalassemia mayor yang mendapat transfusi multipel. Sari Pediatri 9:178-84.

12. Rahayu H (2012) Faktor - faktor yang mempengaruhi performa sekolah pada anak dengan thalasemia yang menjalani transfusi di RSUPN dr. Cipto Mangunkusmo. Tesis di Fakultas Ilmu Keperawatan, Program Studi Magister Keperawatan, Universitas Indonesia Jakarta.

13. Oliveri NF (1999) The $\beta$-thalassemias. The New England Journal of Medicine 341:99-109.

14. Cao A, Galanello R (2010) Beta-thalassemia. Genetics in medicine 12:61-76.

15. Grow K, Vashit M, Abrol P, Sharma S, Yadav R (2014) Beta thalassemia in India: current status and the challenges ahead. International Journal of Pharmacy and Pharmaceutical Science 6:28-33.

16. Au WY, Li CF, Fang JP, Chen GF, Sun X, Li CG, et al. (2014) Assessment of iron overload in very young children with limited thalassemia care in South China. Hemoglobin 38:119-26.

17. El Beshlawy A, El Tagui M, Hamdy M, El Ghamrawy M, Azim KA, Slaem D et al. (2014) Low prevalence of cardiac siderosis in heavily iron loaded Egyptian thalassemia major patients. Ann Hematol. 93:375-9.

18. Pudjiadi AH, Hegar B, Handryastuti S, Idris NS, Gandaputra EP, Harmoniati ED et al. (2011) Talasemia. dalam pedoman pelayanan medis IDAI. Badan penerbit IDAI Jakarta 2011.

19. Shahramian I, Razzaghian M, Ramazani AA, Ahmadi GA, Noori NM, Rezae AR (2013) The correlation between troponin and ferritin serum levels in the patients with major beta-thalassemia. Int Cardiovasc Res J. 7:51-55.

20. Oudit GY, Moe G (2007) Iron-overload cardiomyopathy associated with iron-overload conditions: incidence, pathophysiology, and treatment. Cardiology Round 12: 3 .

21. Peela JR, Jarari AM, Hai A, Rawal AK, Kolla AD, Sreekumar S, et al. (2010) Cardiac biomarkers: the troponins and CKMB. Ibnosina Journal of Medicine and Biomedical Science 2:190-7.

22. Hirsch R, Landt Y, Porter S, Canter CE, Jaffe AS, 
Ladenson JH, et al. (1999) Cardiac troponin I in pediatrics: normal values and potential use in the assessment of cardiac injury. J Pediatr. 130:872-7.

23. Shazia Q, Mohammad ZH, Rahman T, Shekhar HU (2012) Correlation of oxidative stress with serum trace element levels and antioxidant enzyme status in beta thalassemia major patients: a review of the literature. Anemia ID270923:1-7.
24. Choudhary M, Vyas RK (2015) Relation of oxidative stress with serum antoxidant enzymes level in thalasemic subjects. International Journal for Pharmaceutical Research Scholars 4:93-8.

25. Rachmilewitz EA, Stern OW, Adamsky K, Amariglio N, Rechavi G, Breda L, et al. (2005) Role of iron in inducing oxidative stress in Thalasemia. Ann N Y Acad Sci. 1054:118-23. 